\title{
Profitability of Wine Grape Growing in the European Union:
}

\section{An Empirical Analysis*}

\author{
Pappalardo Gioacchino, Di Vita Giuseppe, D’Amico Mario \\ University of Catania, Catania, Italy
}

\begin{abstract}
European wine-growing consists of different features for each region of member state, and every European wine area has its specific characteristics, not only as regards the degree of specialisation of wine-growing holdings and soils, but also as regards the size of the vineyard and the varieties of grapes. The concept of profitability has been variously employed in several agricultural economic analyses and its evaluation has allowed to assess the economic performance of farm, according to different perspectives and directions. The purpose of this study was to assess the profitability of wine grape growing among principal EU wine producing countries. It was carried out between 2002 and 2008, the last year available for consulting the Farm Accountancy Data Network (FADN)(15 EU member states). Taking into account FADN data, we estimated the revenues productivity, expressed as Farm Net Value Added per Total Output (FNVA/TO). This indicator allows to observe the best performances of agricultural holdings, expressing the capability to develop new wealth by wine grape growers. The analyses have highlighted several significant differences among EU countries. The results show that in recent years the profitability of European wine grapes farm producers has significantly grown overall and by continuing to aim at production quality and budgeting farm costs the next few years will see a continued decrease in current disparities among member countries above all in terms of income. In relation to main economic indicators (TO and FNVA) wine grape growers in Greece, Austria and Germany show the greatest growth rates in EU. With respect to revenues productivity (FNVA/TO) of EU wine grape growers, Germany, Greece, Spain, and Austria fall while only Italy increases its revenues productivity index. France, the most important wine-producer state in EU, maintains its revenues productivity index substantially unchanged.
\end{abstract}

Keywords: profitability, vine-growing economics, FADN, FNVA, revenues productivity, EU wine

\footnotetext{
* This paper is part of the research project "Analisi economico-gestionali della filiera vitivinicola in Sicilia e valorizzazione delle produzioni”, financing Assessorato Regionale delle Risorse Agricole e Alimentari, Regione Siciliana, and directed by Mario D'Amico. The study is the result of collaboration of all authors.

Pappalardo Gioacchino, Researcher at Agricultural Economics and Politics, Department of Agri-food and Environmental Management (DIGeSA), University of Catania.

Di Vita Giuseppe, Ph.D. in Agro-food Economics, Department of Agri-food and Environmental Management (DIGeSA), University of Catania.

D’Amico Mario, Professor of Agricultrural Economics, Department of Agri-food and Environmental Management (DIGeSA), University of Catania.

Correspondence concerning this article should be addressed to Di Vita Giuseppe, viale Santa Sofia, 98, 95123 Catania. E-mail: gvitae@hotmail.com.
} 


\section{Introduction}

European wine-growing consists of different features for each region of member state, and every European wine area has its specific characteristics, not only as regards the degree of specialisation of wine-growing holdings and soils, but also as regards the size of the vineyard and the varieties of grapes.

During the last decade the studies farms profitability of European countries have become one of the most significant topics in scientific debate (Allanson \& Hubbard, 1999; Bojnec \& Latruffe, 2008; Schmid, 2009) although not enough studies have been carried out on wine sector (Pappalardo, 2005; Bernetti, Casini, \& Marinelli, 2006; Diniz, Katsioloudes, \& Fortunas, 2006; Dilger, 2009).

Generally, many are the factors that influence profitability such as holding characteristics (Ikerd, 1996), the efficiency of market (Stigler, 1961), the socio-economic context, level of quality production (Di Vita, 2002) and the relationship of the holdings with markets (Sporleder, 1992).

The profitability of European wine grape growing by comparing some economic indicators extrapolated from information in the FADN, data banks have already been widely used to analyse the profitability of European agricultural holdings (Csajbok, Lansink, \& Huirne, 2005; Pappalardo, 2005; Kirner \& Bartel-Kratochvil, 2007; Cagliero, 2008; Borsotto, 2009).

According to Porter (1998) recent studies have confirmed "future profitability in the wine grape industry depends on growers achieving economies of scale” (Bryant, 2010) or "on product differentiation” (Di Vita, 2003).

Profitability is also a strategic objective of common agricultural policy and also for wine sector (European Commission, 2007), and several studies have focussed on the action of Common Agricultural Policy of European Union to support the wine sector, with specific reference to the economic effects on wine grape growers, markets and the environment (Martinez-Casasnovas, Ramos, \& Cots-Folch, 2010; K. Erjavec, E. Erjavec, \& Juvancic 2009; Rittberger \& Richardson, 2003).

The main policy instruments for wine sector have been through the establishment of Reform of Common Agricultural Market, by the introduction EU Reg. 479/2008 that has determined the following goals: (1) to increase the competitiveness of the EU's wine producers and limit production constraints; (2) to effort the reputation of EU quality wine, to recover old markets and to win ones in the EU and worldwide; (3) to ensure balance between supply and demand; and (4) to preserve the best traditions of the EU wine production and reinforce the social and environmental fabric of many rural area.

The support for rural development by the European Agricultural Fund for Rural Development (EAFRD)—EU Reg. 1698/2005 is focused on improving the competitiveness of agriculture by supporting, restructuring, development and innovation.

The purpose of this paper is to evaluate the different levels of profitability of wine grape growing among principal EU countries involved in wine grapes production. The level of profitability of European wine grape growing has been analysed by comparing some economic indicators extrapolated from official EU data base: FADN, of which information is from current to 2008.

The article is structured as follows. In the first section, we report a brief description of the European grape wine sector and the actual trend of wine grape cultivation and wine production. Next, we present the 
methodology and describe the data used. The final section sums up the main findings, discusses and main economic implications deriving from the study.

\section{The Context of Wine Production in the European Union}

With specific reference to the viticultural sector within Europe, it is considered strategic in terms of revenue and employment the EU. Wine production in 2006 represented 5\% of the value of EU agricultural output (Lazanyi, 2008) and wine sector actually occupies a significant position in the value of agricultural production in most member states producer, particularly in France and Luxembourg, it rounds 10\%, Italy, Austria, and Portugal register a value around 9\%, and in Spain, it rounds 3\% (Eurostat, 2009).

Due to the economic and financial difficulties in international markets, policies for sustaining the wine industry are mainly aimed at guaranteeing adequate competitiveness through the correct and rational allocation of the internal resources available, respecting the historic and environmental traditions which have always been distinguished in European winemaking.

When wine common market organisation (CMO) was introduced, it did not provide for any restrictions on new plantations and produced very few market policies. Afterwards CMO became more restrictive, with the reinforcement of financial incentives to abandon wine-making and the obligation to distill any over-production (at the end of the 1980s) and with the next reforms to improve the competitiveness of agricultural and promote the restructuring/reconversion of wine grape growing, producing a progressive decrease of vine lands.

Table 1

Trend of Vines Area in the EU (15 States)

\begin{tabular}{|c|c|c|c|c|}
\hline \multirow{2}{*}{ Country } & \multicolumn{2}{|c|}{2002} & \multicolumn{2}{|c|}{2008} \\
\hline & Hectares & $\%$ & Hectares & $\%$ \\
\hline \multirow[t]{2}{*}{ Spain } & $1,159,559$ & 35.8 & $1,088,121$ & 35.6 \\
\hline & 100 & & 94 & \\
\hline \multirow[t]{2}{*}{ France } & 872,660 & 27.0 & 816,334 & 26.7 \\
\hline & 100 & & 94 & \\
\hline \multirow[t]{2}{*}{ Italy } & 774,550 & 23.9 & 715,312 & 23.4 \\
\hline & 100 & & 92 & \\
\hline \multirow[t]{2}{*}{ Portugal } & 220,191 & 6.8 & 217,296 & 7.1 \\
\hline & 100 & & 99 & \\
\hline \multirow[t]{2}{*}{ Germany } & 102,955 & 3.2 & 102,026 & 3.3 \\
\hline & 100 & & 99 & \\
\hline \multirow[t]{2}{*}{ Greece } & 54,437 & 1.7 & 63,321 & 2.1 \\
\hline & 100 & & 116 & \\
\hline \multirow[t]{2}{*}{ Austria } & 48,728 & 1.5 & 48,269 & 1.6 \\
\hline & 100 & & 99 & \\
\hline \multirow[t]{2}{*}{ Luxembourg } & 1,309 & 0.04 & 1,289 & 0.04 \\
\hline & 100 & & 98 & \\
\hline \multirow[t]{2}{*}{ Others } & 650 & 0.02 & 880 & 0.03 \\
\hline & 100 & & 135 & \\
\hline \multirow{2}{*}{ EU (15 states) } & $3,235,040$ & 100.0 & $3,052,849$ & 100.0 \\
\hline & 100 & & 94 & \\
\hline
\end{tabular}

Note. Source: Eurostat, 2011.

In fact, as regard the evolution of vineyard surfaces all over the period taken into account, from 2002 to 2008 
(see Table 1), European Union has recorded a limited, but steady reduction in cultivated lands, with a decrease of $6 \%$ of total vines areas. Almost all countries have gradually decreased the surface of their vineyards, with the exception that Greece shows an increase of $16 \%$ of viticultural surfaces.

In 2008, Spain was the leader with one million hectares covered by vineyards, which represented the $35.6 \%$ of the EU total vine land. At the same time Spain showed a reduction of $6 \%$ compared to 2002. France was the second state of all European Union (816,334 hectares) with a share of 26.7\% of the EU total.

In Italy a greater reduction than in France has been observed (8\%). In 2008, Italy overall had a wine grape growing surface of 715,312 hectares, which covered the $23.4 \%$ of all European vine areas. Portugal, Germany, Austria and Luxembourg decreased slightly their viticultural surfaces, with rates included between $1 \%$ and $2 \%$.

In 2008 average wine production in the main State of European Union was below 16 million tons. From 2002 (year of introduction of euro) to 2008, European production decreased by 3\% (see Table 2).

Table 2

Trend of Wine Production in the EU (15 States)

\begin{tabular}{|c|c|c|c|c|}
\hline \multirow{2}{*}{ Country } & \multicolumn{2}{|c|}{$2002-2004$} & \multicolumn{2}{|c|}{ 2006-2008 } \\
\hline & Tons & $\%$ & Tons & $\%$ \\
\hline \multirow[t]{2}{*}{ France } & $5,219,918$ & 31.9 & $4,753,531$ & 29.9 \\
\hline & 100 & & 91 & \\
\hline \multirow[t]{2}{*}{ Italy } & $4,727,514$ & 28.9 & $4,613,016$ & 29.0 \\
\hline & 100 & & 98 & \\
\hline \multirow[t]{2}{*}{ Spain } & $4,056,201$ & 24.8 & $4,160,348$ & 26.1 \\
\hline & 100 & & 103 & \\
\hline \multirow[t]{2}{*}{ Germany } & 933,400 & 5.7 & 980,967 & 6.2 \\
\hline & 100 & & 105 & \\
\hline \multirow[t]{2}{*}{ Portugal } & 739,842 & 4.5 & 634,091 & 4.0 \\
\hline & 100 & & 86 & \\
\hline \multirow[t]{2}{*}{ Greece } & 392,684 & 2.4 & 492,419 & 3.1 \\
\hline & 100 & & 125 & \\
\hline \multirow[t]{2}{*}{ Luxembourg } & 14,427 & 0.1 & 13,200 & 0.1 \\
\hline & 100 & & 91 & \\
\hline \multirow[t]{2}{*}{ Austria } & 262,118 & 1.6 & 250,477 & 1.6 \\
\hline & 100 & & 96 & \\
\hline \multirow[t]{2}{*}{ Others } & 14,182 & 0.1 & 12,151 & 0.1 \\
\hline & 100 & & 86 & \\
\hline \multirow[t]{2}{*}{ Europe (15 sates) } & $16,360,285$ & 100.0 & $15,910,200$ & 100.0 \\
\hline & 100 & & 97 & \\
\hline
\end{tabular}

Note. Source: Eurostat, 2011.

France and Italy, which have reduced their average production, respectively by $9 \%$ and $2 \%$, represent the leader all over the world as wine producers, registering each one a share around $29 \%$ of European total production.

Spain (26.1\% of total production), Germany (6.2\% of EU production), and Greece (3.1\% of EU production) 
are the only states that reveal from 2002 to 2008 a moderate growth, including between 3\% and 25\%.

Well behind follows Austria and Luxembourg, both with wine productions decreasing, which weight upon total European production respectively $1.6 \%$ and $0.1 \%$.

\section{Methodology}

The profitability of European wine grape growing has been analysed by comparing some economic indicators extrapolated from information in the FADN which is from current to 2008. FADN is an annual survey carried out by the Member States of the European Union. It was launched in 1965, when Council Regulation 79/65 established the legal basis for the organisation of the network. Actually the FADN is the only source of harmonised micro-economic data in all EU countries. Holdings are selected according to economic size unit (ESU), including only those farms deemed to be commercial. A commercial farm is defined as a farm which is large enough to provide a main activity for the farmer and a level of income sufficient to support his or her family.

The economic indicators data have been extrapolated from FADN as follows: the total output (TO); the costs; and FNVA.

From these, we estimated a specific profitability indicator: revenues productivity (FNVA/TO) which provides an indicator of the capacity to develop new wealth in wine grape growing. The revenues productivity was calculated by comparing the FNVA (gross production minus intermediate consumption, depreciation, subsidies and taxes) with the TO (INEA, 2003, 2009).

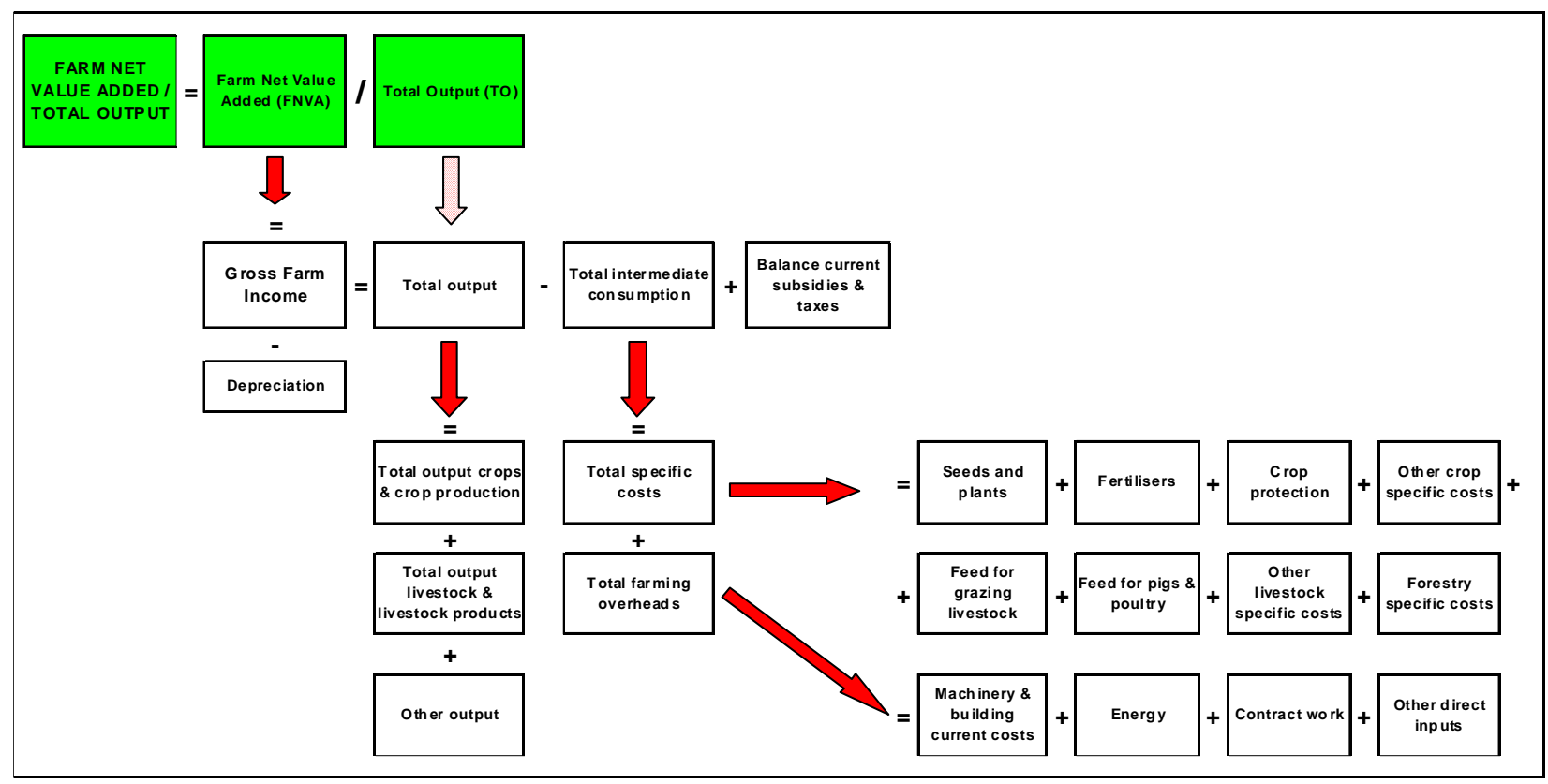

Figure 1. Outlook of profitability indicator (FNVA/TO).

As reported in Figure 1, the economic indicators from which we obtained the revenues productivity is calculated according to the following schemes:

$\mathrm{TO}=$ Total output crops and crop production $=$ Sales + Farm use + Farmhouse consumption

Costs $=$ Total intermediate consumption (specific cost + farming overheads) + Depreciation 
FNVA $=$ Gross farm income - Depreciation

where:

Total intermediate consumption includes total specific costs and farming overheads arising from production in the accounting year.

Specific costs include crop-specific inputs (seeds and seedlings, fertilizers, crop protection products, and other specific crop costs).

Farming overheads include supply cost linked to production activity but not linked to specific lines of production.

Depreciation concerns plantations of permanent crops, farm buildings and fixed equipment, land improvements, machinery and equipment and forest plantations. It is determined on the basis of the replacement value.

Gross farm income $=$ Total output - Intermediate consumption + Balance current subsidies and taxes

The analysis was carried out between 2002 (introduction of the euro) and 2008, the last year available for consulting the FADN which is why the study was of an EU of 15 states.

Taking into account these profitability indicators the study aimed at comparing wine grape growing of main wine production countries of EU member states.

Finally, the FNVA/TO was calculated by comparing the FNVA with the TO (INEA, 2003, 2009). The FNVA/TO ratio provides an indicator of the ability to develop new wealth distributed in the form of capital interest, work (family and waged) and revenue (INEA, 2003, 2009; De Benedictis \& Cosentino, 1979).

\section{Results and Discussion}

In this section the profitability of wine grape growing in the European Union has been examined. The profitability of European wine grapes farm producers has been carried out by comparing some economic and efficiency indicators extrapolated from information in the FADN, taking into account the period included between 2002 and 2008.

With respect to TO, from 2002 to 2008, the countries with the greatest increases were Greece (50\%), Austria (18\%) and Germany (13\%). Portugal showed significant declines (-11\%) while France (3\%) and Italy (-1\%) remained substantially stable (see Table 3 ).

In terms of absolute values, Luxembourg revealed, in 2008, the highest value of TO ( $€ 23,874$ per hectare); confirming the high quality levels of its certified wines. With respect to the other states, following Germany ( $€$ 15,344 per hectare), Austria (€/ha 12,783) and France (€/ha 11,641). Spain ( $€ /$ ha 2,222$)$ and Portugal ( $€ /$ ha 3,706$)$ evidenced the lowest values of TO in all European Union.

In relation to costs (intermediate consumption), all the member states showed a steady increase. From 2002 to 2008, a growing increase has been observed in Greece (+38\%), Germany $(18 \%)$, Italy $(+17 \%)$ and Spain (+14\%), whereas the values in Portugal have been basically unchanged compared to 2002.

Even in this case, Luxembourg shows the highest total cost (€/ha 14,049) while in Germany and in Austria total cost has been fixed above 10 thousand Euros per hectare, respectively €/ha 9,201 and €/ha 8,335.

All Mediterranean countries reveal the lowest costs in absolute, particularly, Spain (€/ha 860) and Portugal ( $€ /$ ha 2,081) are the states whose total costs are less expensive than the rest of European countries. 
Table 3

Economic Indicators in Main EU State Members

\begin{tabular}{|c|c|c|c|c|}
\hline \multirow{2}{*}{ Country } & \multicolumn{2}{|c|}{ TO (euro/ha) } & \multicolumn{2}{|c|}{ Costs (Intermediate consumption) (euro/ha) } \\
\hline & 2002 & 2008 & 2002 & 2008 \\
\hline \multirow[t]{2}{*}{ Germany } & 13,562 & 15,344 & 7,827 & 9,201 \\
\hline & 100 & 113 & 100 & 118 \\
\hline \multirow{2}{*}{ Greece } & 5,638 & 8,447 & 2,665 & 3,667 \\
\hline & 100 & 150 & 100 & 138 \\
\hline \multirow[t]{2}{*}{ Spain } & 2,124 & 2,222 & 754 & 860 \\
\hline & 100 & 105 & 100 & 114 \\
\hline \multirow[t]{2}{*}{ France } & 11,276 & 11,641 & 5,492 & 5,771 \\
\hline & 100 & 103 & 100 & 105 \\
\hline \multirow[t]{2}{*}{ Italy } & 8,566 & 8,463 & 3,710 & 4,323 \\
\hline & 100 & 99 & 100 & 117 \\
\hline \multirow[t]{2}{*}{ Luxembourg } & 24,726 & 23,874 & 13,115 & 14,049 \\
\hline & 100 & 97 & 100 & 107 \\
\hline \multirow[t]{2}{*}{ Austria } & 10,818 & 12,783 & 5,942 & 8,335 \\
\hline & 100 & 118 & 100 & 140 \\
\hline \multirow[t]{2}{*}{ Portugal } & 4,171 & 3,706 & 2,111 & 2,081 \\
\hline & 100 & 89 & 100 & 99 \\
\hline
\end{tabular}

Note. Source: FADN, 2011.

For that concern FNVA, it has been calculated by subtracting depreciation ${ }^{2}$ from Gross Farm Income and it has been referred to surface, expressed in hectares (FNVA/ha).

Also for this economic indicator, as was expected, Luxembourg, Germany, and Austria are the member states with highest FNVA/ha. Apart from absolute values, the greatest increases, from 2002 to 2008, were shown by Greece (+25\%), Austria (8\%), and Germany (+6\%) and almost all European countries increased their FNVA with the exception of Luxembourg and Portugal that showed pronounced falls, respectively by $16 \%$ and $13 \%$.

The last economic indicator, that we named revenues productivity, is measured by the FNVA/TO ratio, and it allows to observe the best performances of considered holdings. This indicator expresses the capability to develop new wealth by agricultural holdings. It ranges from zero to one and as coefficient tends to unity as greater is productivity of revenues, and consequently bigger will be the efficiency of holdings.

With respect to coefficient of revenues productivity (FNVA/TO), in 2008 Greece, Spain, and Italy evidence best economic results and highest values, respectively equal to $0.75,0.68$ and 0.60 . The remaining countries show coefficient values included between 0.47 and 0.53 (see Table 4).

From 2002 to 2008, only Italy showed an increase of productivity indicator (+3\%), all rest of sampled countries showed small decreases. Despite the highest coefficient of revenues productivity of all UE member states, Greek data was the most anomalous because of the highest fall with $-17 \%$. This evident incongruity could probably be explained by the fact that FADN database only included agricultural holdings selected according to economic size unit (ESU), and deemed to be commercial; indeed small wine grape holdings, which represented the prevalence of Greek vineyards, escaping from FADN sample observation.

\footnotetext{
${ }^{2}$ Depreciation is the remuneration for the fixed production factors (work, land and capital), whether they be external or family factors.
} 
Table 4

Economic Indicators and Profitability Index

\begin{tabular}{|c|c|c|c|c|c|c|c|c|}
\hline \multirow{2}{*}{ Country } & \multicolumn{4}{|c|}{ FNVA (euro/ha) } & \multicolumn{4}{|c|}{ FNVA/TO } \\
\hline & 2002 & & 2008 & & 2002 & & 2008 & \\
\hline \multirow[t]{2}{*}{ Germany } & 6,857 & & 7,250 & & 0.51 & & 0.47 & \\
\hline & & 100 & & 106 & & 100 & & 93 \\
\hline \multirow[t]{2}{*}{ Greece } & 5,069 & & 6,317 & & 0.90 & & 0.75 & \\
\hline & & 100 & & 125 & & 100 & & 83 \\
\hline \multirow[t]{2}{*}{ Spain } & 1,486 & & 1,514 & & 0.70 & & 0.68 & \\
\hline & & 100 & & 102 & & 100 & & 97 \\
\hline \multirow[t]{2}{*}{ France } & 5,836 & & 5,891 & & 0.52 & & 0.51 & \\
\hline & & 100 & & 101 & & 100 & & 98 \\
\hline \multirow[t]{2}{*}{ Italy } & 5,002 & & 5,083 & & 0.58 & & 0.60 & \\
\hline & & 100 & & 102 & & 100 & & 103 \\
\hline \multirow[t]{2}{*}{ Luxembourg } & 14,802 & & 12,388 & & 0.60 & & 0.52 & \\
\hline & & 100 & & 84 & & 100 & & 87 \\
\hline \multirow[t]{2}{*}{ Austria } & 6,322 & & 6,800 & & 0.58 & & 0.53 & \\
\hline & & 100 & & 108 & & 100 & & 91 \\
\hline \multirow[t]{2}{*}{ Portugal } & 2,194 & & 1,907 & & 0.53 & & 0.51 & \\
\hline & & 100 & & 87 & & 100 & & 98 \\
\hline
\end{tabular}

Note. Source: FADN, 2011.

\section{Conclusion}

In this paper, we have examined the profitability of wine grape growing in the European Union. The profitability of European wine grapes farm producers has been carried out by comparing some economic and efficiency indicators extrapolated from information in the FADN, data banks already widely used to analyse various socio-economic aspects of European farms and in particular income and work. The study has been carried out between 2002 and 2008.

The analyses have highlighted several significant differences among EU countries. The results show that in recent years the profitability of European wine grapes farm producers has significantly grown overall and by continuing to aim at production quality and budgeting farm costs the next few years will see a continued decrease in current disparities among member countries above all in terms of income.

In relation to main economic indicators (TO and FNVA) wine grape growers in Greece, Austria and Germany show the greatest growth rates in EU, over 2002-2008.

With respect to revenues productivity (FNVA/TO) of EU wine grape growers, Germany, Greece, Spain, and Austria fell in 2008 while only Italy increased its revenues productivity index (+3\%). France, the most important wine-producer state in EU, maintained its revenues productivity index substantially unchanged compared to 2002 (-2\%). On the other hand, the higher value of revenues productivity has been observed in Greece, the reasons were probably due to the process of intensification and modernization of agricultural practices bringing about the rise in labour costs.

Despite current policy instruments—such as EU Regulation 1698/2005 on support for rural development and EU Regulation 479/2008 on the Common Organisation Market in wine-several factors of crisis have been observed.

The first one is that the growth rate of production costs is greater than profitability expressed as FNVA per 
hectare. In fact, profitability of high quality wine countries, like Germany, Austria, France, and Luxembourg grows less than the costs of production. Therefore, it will be easier to deal with and overcome the current economic crisis which has hit not only the wine sector but also the entire planet's primary sector.

In this context, public intervention to sustain this sector over the next few years to maintain the competitiveness of European wine grapes farm producers should continue to aim at policies of quality and food safety while respecting the environment and wine-making tradition which member countries have had for centuries. With regard to public intervention the following proposals have emerged: to increase farm profitability through a reduction of taxes and fees, to promote the export in non-EU markets, and to promote investments on quality wine production.

\section{References}

Allanson, P., \& Hubbard, L. (1999). On the comparative evaluation of agricultural income distributions in the European Union. European Review of Agricultural Economics, 26(1), 1-17.

Bernetti, I., Casini, L., \& Marinelli, N. (2006). Wine and globalisation: Changes in the international market structure and the position of Italy. British Food Journal, 108, 306-315.

Bojnec, S., \& Latruffe, L. (2008). Measures of farm business efficiency. Industrial Management and Data Systems, 108, $258-270$.

Borsotto, P., Cagliero, R., \& Trione, S. (2009). Una valutazione della competitività delle aziende vitivinicole piemontesi, INEA (Eds): La competitività delle aziende vitivinicole piemontesi, Analisi regionali, Roma.

Bryant, R. (2010). Wine sector in decline, IBISWorld. Retrieved from http://www.smartcompany.com.au/food-and-beverages/20100407-grape-growing-sector.html

Cagliero, R. (2008). La competitività del sistema agro-alimentare italiano sulla base dei dati FADN. In Pesce A. (eds.) Sistemi e strumenti per rafforzare la competitività nell'agro-alimentare, Quaderno informativo Rete Nazionale per lo Sviluppo Rurale, Roma.

Csajbok, I., Lansink, A. O., \& Huirne, R. (2005). Effects of management information from FADN on profitability of Dutch potted-plant firms. Agricultural Economics, 33, 325-331.

De Benedictis, M., \& Cosentino, V. (1979). Economia dell'azienda agraria: teoria e metodi. Bologna: Il Mulino.

D’Amico, M., La Via, G., (2008). L’intervento pubblico a sostegno della competitività in agricoltura. In Società Italiana di Economia Agraria (SIDEA) (Eds.), Agricolture e mercati in transizione, Franco Angeli, Milano, 148-196.

Di Vita, G. (2002). La gestión de la calidad según las normas ISO 9000:1994 en el sector agro-alimentario europeo: el caso de una región mediterránea. Información Técnica Económica Agraria (ITEA), Zaragoza (España), 98(1), 54-70.

Di Vita, G. (2003). Circolo della qualità e certificazione di processo nel comparto vinicolo siciliano un caso studio. Rivista di Economia Agroalimentare, 1, aprile 2003, 87-111.

Dilger, A. (2009). In vino veritas: The effects of different management configurations in German viniculture. Journal of Wine Research, 20, 199-208.

Diniz, F. J., Katsioloudes, M., \& Fortunas, S. P. (2006). The competitiveness of the Portuguese wine sector and a case study of exports and activity diversification in the Vinhos Verdes region. Proceedings from the 98th EAAE Seminar "Marketing Dynamics within the Global Trading System: New Perspectives”, Chania, Crete, Greece, 29 June-2 July, 2006.

Erjavec, K., Erjavec, E., \& Juvancic, L. (2009). New wine in old bottles: Critical discourse analysis of the current common EU agricultural policy reform agenda. Sociologia Ruralis, 49, 41-55.

European Commission. (2007). What is the current situation of the European Union's wine sector? Retrieved from http://www.ec.europe.eu/agriculture/markets/wine/index.en.htm

European Commission. (2011). The farm accountancy data network (FADN), Data collection. Retrieved from http://www.ec.europa.eu/agriculture/rica/index.cfm

Eurostat.(2009).Statistics,statistics by theme, agriculture and fisheries. Retrieved from http://www.epp.eurostat.ec.europa.eu/portal/page/portal/statistics/themes

Ikerd, J. (1996). Sustaining the profitability of agricultural. paper presented at the extension pre-conference: The Economist's Role in the Agricultural Sustainability Paradigm, San Antonio, TX, July 27, 1996. 
Istituto Nazionale di Economia Agraria (INEA). (2003). Risultati economici secondo la RICA. Roma: INEA.

Istituto Nazionale di Economia Agraria (INEA). (2009). La competitività delle aziendevitivinicole piemontesi. Roma: INEA.

Kirner, V. L., \& Bartel-Kratochvil, R. (2007). Effect of off farm income, farm size, natural disadvantage and farming system on the sustainability of dairy farming in Austria-An empirical approach on the basis of farm accountancy data. Berichte Uber Landwirtschaft, 85, 195-213.

Lazanyi, J. (2008). Trends in wine production and trade. Applied Studies in Agribusiness and Commerce, 2(1-2), 137-146.

Martinez-Casasnovas, J. A., Ramos, M. C., \& Cots-Folch, R. (2010). Influence of the EU CAP on terrain morphology and vineyard cultivation in the Priorat region of NE Spain. Land Use Policy, 27, 11-21.

Pappalardo, G. (2005). Analisi della competitività dei comparti vitivinicolo ed olivicolo oleario siciliani nell'Unione Europea, CORERAS, Palermo.

Porter, M. E. (1998). The competitive advantage: Creating and sustaining superior performance. N.Y.: Free Press.

Rittberger, B., \& Richardson, J. (2003). Old wine in new bottles? The commission and the use of environmental policy instruments. Public Administration, 81, 575-606.

Schmid, D. (2009). Productivity comparison between Switzerland and Baden-Wurttemberg. Agrarforschung, 16, 118-123.

Sporleder, T. L. (1992). Managerial economics of vertically coordinated agricultural firms. American Journal of Agricultural Economics, 74(5), 1226-1231.

Stigler, G. J. (1961). The economics of information. Journal of Political Economy, 69(3), 213-225. 